\title{
Türkiye'de Televizyonlarda Kanaat Üretimi: Haber Kanallarındaki Tartışma Programları ve Kanaat Teknisyenleri ${ }^{1}$
}

\section{Can Ertuna} \\ Dr. \\ canertuna@gmail.com \\ Orcid: 0000-0002-3734-7345
}

\begin{abstract}
The Production of Opinion on Turkish TV Channels: Discussion Programs and Technicians of Opinion

This study aims to demonstrate how the opinion is produced and technicians of opinion are selected for debate programs in TV news channels in Turkey. For this purpose, discussion programs that were broadcast between November 24-2016 and October 4, 2016 on three main news channels; NTV, Cnn Türk and Habertürk were analysed. In addition to this, in depth interviews were conducted with the journalists working in these channels as well as the experts who appeared on these screens and with those who had been sidelined because of political reasons. The study demonstrates that technicians of opinion in these programs are selected through an effective filtering mechanism. Further, it is found that the social and political inequalities that already exist in the society are also manifested in different aspects of these programs which are instrumentalised for the reproduction of the official and hegemonic rhetoric.
\end{abstract}

keywords: Mainstream, News Channel, Discussion Program, Technician of Opinion

1 "Bu makalede temel alınan araştırma kapsamında ulaşılan bulgular, yazarın Galatasaray Üniversitesi, Sosyal Bilimler Enstitüsü çatısı altındaki Medya ve IIletişim Çaışmaları doktora programı kampsamında tamamladığı tez çalışması (Ertuna, 2018) çerçevesinde yürütülen bir araştırmanın çıktılarına dayanmaktadır."

DOI: $10.16878 /$ gsuilet.496644 


\section{Résumé}

\section{La production de l'opinion à la télévision en Turquie: débats télévisés et les techniciens d'opinions sur les chaînes d'information}

Cette étude cherche à démontrer la façon dont est produite l'opinion publique et comment les techniciens d'opinions sont sélectionnés pour les débats télévisés dans les chaînes d'information en Turquie. À cette fin, les programmes de discussions diffusées entre le 24 novembre 2016 et le 4 octobre 2016 sur trois chaînes principales: NTV, CNN Türk et Habertürk ont été analysés. Des entretiens de fonds ont, en outre, été conduits avec des journalistes travaillant au sein de ces chaînes, ainsi qu'avec des experts apparaissant dans ces émissions et ceux qui en ont été écartés pour des raisons politiques. L'étude démontre que les leaders d'opinions dans ces programmes sont sélectionnés à travers un filtre mécanique efficace. Enfin, les résultats montrent que les inégalités sociales et politiques de la société apparaissent également dans les différents aspects de ces programmes, qui sont des instruments de reproduction de la réthorique officielle et hégémonique.

mots-clés: Grand Public, Chaîne d'Information Continu, Débât Télévisé, Technicien d'Opinion 


\section{Öz}

Bu çalışmanın amacı, Türkiye'deki haber kanallarında yayınlanan tartışma programlarındaki kanaat üretim mekanizmasını ve bu sürecin başlıca aktörü olan kanaat teknisyenlerinin seçim ve filtrelenme kriterlerini ortaya koyabilmektir. ÇaIışma kapsamında NTV, CNN Türk ve Habertürk'te, 24.10.2016 - 04.10.2016 tarihleri arasında, hafta içi akşam saatlerinde yayınlanan tartışma programları, bu programların formatları, katıımcı profilleri, moderasyon biçimleri incelenmiş ayrıca, araştırmanın odağında yer alan üç haber kanalından haberciler, bu kanallarda yayınlanan programa katılan kanaat teknisyenleri ve bir süre öncesine kadar haber tartışma programlarına çağrıldığı halde artık davet almayan eski konuklarla görüşülmüştür. Elde edilen veriler, programlara davet edilen kanaat teknisyenlerinin etkili filtreleme mekanizmalarına tabi olduklarını ortaya koymaktadır. Ayrıca siyasal ve toplumsal eşitsizlikler de bu programlarda doğrudan yansımasını bulmakta ve bu yapımlar egemen söylemin yeniden üretildiği biçimde araçsallaştırılmaktadirlar.

anahtar kelimeler: Ana akım, haber kanalı, tartışma programı, kanaat teknisyeni 


\section{Giriş}

Güncel araştırmalara göre, Türkiye'de toplumun haber kaynağı olarak başvurduğu araçlar arasında televizyon, gazeteye karşı hakimiyetini pekiştirmektedir². Her ne kadar, özellikle kentsel alanlarda haber tüketimi televizyonlardan çok çevrimiçi mecralara kaymaya başlasa da internet sitelerinin içeriklerinin halen ağırlıklı olarak konvansiyonel medya araçlarındaki ürünlerle dolu olduğunu ya da o ürünlerin halen çevrimiçi gündemi belirlediğini vurgulamak gerekmektedir. Özellikle kriz dönemlerinde kitlelerin haber alma ihtiyacını gidermek için televizyonlara yöneldiği ortaya çıkmaktadır. Bu çalışmaya konu olan dönemde, Türkiye'yi sarsan en önemli olay olarak nitelendirilebilecek 15 Temmuz 2016 darbe girişimi hakkında KONDA araştırma şirketi tarafından yürütülen bir araştırma, toplumun \%67'sinin darbe girişimini televizyonlardan öğrendiğini ortaya koymaktadır³.

Toplumun geniş kesimleri salt haber almak için değil, haberi anlamlandırmak için de ekran karşısına geçmektedir. Bu çerçevede, sıcak gündemin stüdyolara çağııılan konuklarla değerlendirildiği haber tartışma programları, Türkiye'deki haber kanallarının başat program formatlarından biridir. Bu programlar, doğrudan bir habercilik faaliyeti olarak değerlendirilemeseler de televizyonlarda o günün gazetecilik alanının kural, işleyiş ve eğilimlerini barındıran yapımlar olarak nitelendirilebilirler. Tartışma programları, genellikle fiziksel olarak da haber merkezlerinin içinde yer alan ve kendileri de haber üretimi süreçlerine katılan yönetici, editor, sunucu ve yapımcıların ortak üretimleri olarak ortaya çıkmaktadır. Bu çalışmada, üç ana akım haber kanalında (NTV, Cnn Türk ve Habertürk), 15 Temmuz 2016'daki darbe girişiminden hemen sonra ve olağanüstü hal döneminde düzenlenen tartışma programları bağlamında kanaat üretim sürecinin, habercilik alanına dışarıdan buyur edilen ekran uzmanlarının katıımıyla nasıl gerçekleştirildiği mercek altına alınmaktadır.

\section{Teorik Arka Plan}

Stuart Hall (1973, s. 235), bir konuya haber değeri katan şeyin nötr, tarafsız rutin eylemler bütünü olarak göründüğünü, ancak aslında analiz edilmesi gerekenin haber ideolojisinin parçaları olduğunu ifade eder. Leon Sigal'e göre (1986, s. 15) "haber, ne olduğu değil, bir kişinin olanın ya da olacak olanın ne olduğunu söylediği şeydir". Dolayısıyla haber ve gazetecilik alanındaki diğer "ürünleri" anlamak için, bu kişilerin kim olduğunun, kaynakların kimlerden oluştuğunun ve gazetecilerin bunlarla ilişkilerinin sorgulanması gerekmektedir (Schudson, 2002, s. 255). Anılan kişiler arasında haber kaynakları olduğu kadar, haberi yorumlayan, gündemi değerlendiren ve kulis bilgileri paylaşan televizyon uzmanları da vardır. Bazıları medya kuruluşlarında görev yapsa da birçoğunun farkı mesleklere sa-

2 http://www.digitalnewsreport.org/survey/2018/turkey-2018/ (Erişim tarihi: 14.06.2018)

3 http://t24.com.tr/haber/konda-arastirmasi-darbeye-karsi-sokaga-cikanlarin-yuzde-53u-erdoganin-cagrisiyla-karar-verdi,354033 (Erişim tarihi: 12.06.2018) 
hip olduğu bu zümrenin üyeleri, stüdyolara geldiklerinde medya sistemine dahil olmakta ve bir yandan kendi birikimlerini habercilik alanının kural ve eğilimleriyle çerçevelerken, diğer yandan da ana akımın sınırlarının (yeniden) çizilmesinde önemli rol oynamaktadırlar.

Televizyon kanallarında boy gösteren uzmanlar, medya çalışmalarında yer yer ele alınmış ve gündem belirleme sürecindeki etkileri anlaşılmaya çalışılmıştır. Örneğin Nimmo ve Combs (1992, s. 20), çalışmalarında "medya uzmanlarının"etkilerini ortaya koyabilmek için onları, yasama, yürütme ve yargının yanı sıra "4. kuvvet" olarak anılan medyanın yanında, bir beşinci kuvvet olarak tanımlamaktadırlar. Tartışma programlarındaki kanaat üretim süreçlerini temelde, 2016'da Türkiye'deki iktidar-medya ilişkileri bağlamında masaya yatırma amacı taşıyan bu çalışmada, mevcut haliyle, ana akım medyanın ve bu mecrada boy gösteren kanaat teknisyenlerinin, yukarıda aktarıldığı şekilde, iktidarı denetleyebilecek bir dördüncü (ya da beşinci) kuvvet oldukları varsayılmamaktadır. Bu bağlamda, araştırma konusu, gazetecilik faaliyetinin, neoliberalizmin kurumsal, etik ve işlevsel olarak dönüşüme uğrattığı alanlardan biri olduğu düşüncesiyle, temelde eleştirel bir yaklaşım bağlamında ele alınmaktadır. Marksist gelenekten beslenen böyle bir anlamlandırma çabasında medya, sınıf çatışmasının yaşandığı ideoloji alanının bir parçası olarak konumlandırııı (Bennett, 1982, s. 44). Eleştirel yaklaşımın Frankfurt okulu, kültürel çalışmalar gibi farklı akımarı, bu üstyapısal alandaki işleyişin anlaşılması (ve gerektiğinde dönüştürülmesi) üzerine yoğunlaşmışlardır. Bu çalışmada, ekonomi-politik temelli açıklamaların yanı sıra, bu düşünce okulunun doğrudan içinde yer almasa da, farklı düzlemlerde eleştirel çözümleme olanakları sağlayan Fransız sosyolog Pierre Bourdieu'nün zengin analiz çerçevesinden de yararlanılmıştır.

İdeolojinin günlük hayata nüfuz etme mekanizmalarını çözümleme arayışında - ideoloji kavramını "simgesel otorite", "simgesel iktidar" ya da "simgesel şiddet" gibi kavramlarla ikâme eden - iletişim çalışmaları alanına sosyoloji disiplininin birikmini taşıyan bir düşünür olan Pierre Bourdieu, iktidar-medya ilişkilerinin anlaşılmasında da önemli çözümleme araçları sunmaktadır. Nicholas Garnham ve Raymond Williams (1986, s. 118) Weber ve Durkheim'ın teorik mirasından beslenen Bourdieu'nun özellikle yapısalcı Marksist çözümlemelerden birçok noktada ayrıştığını belirtseler de Fransız düşünürün "eleştirel" yaklaşımı ile tarihsel materyalizmin izleğinden uzak düşmediğini vurgulamaktadırlar. Bu bakış açısına göre değerlendirildiğinde, Bourdieu, simgesel iktidar üzerine yoğunlaşarak, üretim biçimlerinin ortaya çıkardığı nesnel toplumsal koşullar ile farklı sınıfların bilinç ve eylemleri arasındaki ilişkileri ortaya koymakta (Garnham ve Williams, 1986, s. 129) ve böylelikle, özellikle kültürel üretimin, ekonomik sermaye dışında farklı sermaye türleriyle (toplumsal, siyasal, simgesel) ilişkisinin sergilenmesi bakımından önemli bir referans noktası oluşturmaktadır.

Bourdieu, yaşamının son döneminde ilgisini yoğunlaştırdığı medya alanına 
dair kaleme aldığı, kısa ancak etkili eseri Televizyon Üzerine'de, kıymeti ekran görünürlügünden menkul televizyon uzmanlarını, "fast thinker" olarak adlandırmıştır. Bu tanım, kitapta, önceden hazmedilmiş, önceden düşünülmüş, hızla üretilip, hızla tüketilen görüşlere referansla Ingilizce olarak kullanmaktadır ${ }^{4}$. Bourdieu'ye göre televizyona çıkanların - bir şey söylemek ya da söyleyememek kaygısıyla - bu mecrada yer almayı kabul etmeleri, kendilerini gösterme amacı taşımakta ve felsefeci Berkeley'in vurguladığı gibi "algılanmış olma" itkisinin bir var oluş tanımına (olma) dönüşmesiyle birlikte, üretimlerinin biçimi de değişmektedir. Bu sürecin parçası olanların, kısa ve düzenli aralıklarla ortaya konan yapıtları, bu hedefe yönelik olarak gerçekleştirilmektedir (Bourdieu, 2000, s. 18). Bu çalışmada, Bourdieu'nün antik Yunan'dan esinlenerek "yeni entelektüelleri" eleştirel bir çerçevede tanımlamak için kullandığı ve "sabit fikir" olarak Türkçe'ye çevrilebilecek "doksa" kavramından türetilen "doksozof" tanımı ve bunun Türkçe çevirisi olabilecek "sabit fikir aşığı" ya da "kanaat sevici" nitelemeleri üzerinden, Türkiye'de ilgili çalışmalarda sıklıkla kullanıldığı şekliyle "kanaat teknisyeni" nitelemesi, ana akım medya düşünürlerini betimlemek için, "fast-thinker" teriminin yerine, tercih edilmiştir.

Antik Yunan'da kanaatler (doksa), bilimsel bilginin (episteme) karşısına, zıt bir kavram olarak konumlandırılmıştır. Bu çerçevede, Ulus Baker'e göre, günümüz kitle medyasında üzerine konuşulan, bilimsel akıldan farklı olarak, üretim kurallarına uymak zorunda olan kanaat iddialarıdır ve bu süreç iletişimin özü haline gelmiştir (Baker, 2015, 44). Egemenlerin bakış açılarını yansıtan bu kanaatler, bilimsel bilgiden farklı olarak, iktidar mekanizmalarının doğallaştırımasını ve Bourdieu'den esinle ifade edilecek olursa, simgesel şiddetin kabullenilmesini sağlar. Calhaun (2016, s. 101), doksaların (kanaatlerin) toplumsal boyutuna işaret eder. Bu bağlamda, toplumsal olarak üretilen bir anlayıșın ürünü olan doksalar, kültüre ve alana göre değişir. Yukarıda da kısaca değinildiği gibi, Bourdieu de bu şekilde tanımlanan doksalar temelinde hareket eden bir tür "yeni entelektüel"den bahsetmekte ve bu grubun, seçim geceleri için gazetecilik yorumlarına ve kamuoyu yoklamalarının eleştirel olmayan özetlerine indirgenmiş bir sosyal bilim ürettiklerini söylerek Plato'dan esinle onlara, "kendilerini bilge sanan kanaat teknisyenleri" anlamında, "doksozof" adını vermektedir (Bourdieu, 1998a, s. 7).

Fransızca kökenli teknisyen kelimesi, Türk Dil Kurumu tarafından "teknikçi" olarak tanımlamakta ve açıklama olarak da "bir işin bilim yönünden çok, uygulama ve pratik yönü ile uğraşan kimse, teknik adam" denmektedir ${ }^{5}$. Bu kişiler, konunun, iletişim koşullarının -özellikle de zaman sınırlamasının - dayatımış ol-

4 Çevirmen Turhan Ilgaz da Bourdieu'nün bu yaklaşımına sadık kalarak Türkçe metin boyunca "fast-thinker" tanımını kullanmış, kitabın kaleme aldığı sunuş bölümünde fast-thinker tanımını, "malumatfuruş ekran aydınları" olarak açmıştır. Malûmatfüruş, Osmanlıca-Türkçe Ansiklopedik Lûgat'ta, bilgi satan, bilgiçlik taslayan olarak Türkçe'ye çevrilmektedir (Devellioğlu, 1999, s. 578).

5 http://tdk.org.tr/index.php? option=com_gts\&arama=gts\&guid=TDK. GTS.5996cd27241b94.56649847 (Erişim tarihi: 18.08.2017). 
masından ötürü entelektüel özerkliklerini yitirmekte (Bourdieu, 2000, s. 20), ve bir bilim insanından, teknisyene dönüşmektedirler. Bahadır Türk'e göre (2012, s.29), entelektüel alandaki genel bir dönüşümün tarifinde yararlanılan kanaat teknisyenleri tanımıyla anlatılmak istenen, siyasetin sorunlarını iş adamlarının, siyasetçilerin ve siyaset üzerine yazan gazetecilerin ağzıyla ortaya koyan "sözde-uzmanlardır". Bu kişiler, akşam kuşaklarında ana akım haber kanallarının saatlere yayılan tartışma programlarında, editor ve sunucuların seçimi ve yönlendirmeleriyle, bir konunun Bu bağlamda programlardaki kanaat üretim süreçlerini anlamlandırmak için kanaat teknisyenlerinin kim olduğu kadar, onların medya profesyonelleri tarafından seçilme kriterlerinin anlaşılması, programlardaki tartışma sahnesinin inşasında kullanılan siyasi ve sosyal parametrelerin çözümlenmesi de gerekmektedir.

\section{Yöntem}

Çalışma kapsamında NTV, CNN Türk ve Habertürk'te, 24.10.2016 04.10.2016 tarihleri arasında, hafta içi akşam saatlerinde yayınlanan tartışma programları, bu programların formatları, katılımcı profilleri, moderasyon biçimleri incelenmiştir. Bu tarih aralığının seçilmesinin başlıca nedeni, Ekim ayı ortası itibariyle televizyon kanallarının yeni yayın dönemi programlarının belirlenmiş olması ve istisnai bir durum olmaması halinde programların ve sunucuları bir yaz mevsimine kadar süreklilik göstermesidir. Bu dönem, 15 Temmuz darbe girişimi sonrası, olağanüstü hal sürecindeki ilk yayın dönemi olarak nitelendirilebilir. Bu süre içinde NTV'de, "Doğrudan Siyaset", "Bugün Yarın", "Basın Odası", "Yakın Plan" adlı programlar yayına girmiştir. CNN Türk'te "Ne Oluyor?" ve "Tarafsız Bölge", Habertürk TV'de ise "Türkiye'nin Nabzı", "Teke Tek", "Karşıt Görüş" programları akşam kuşaklarında yayınlanmıştır.

NTV, 1996 yılında tekstil ve gayrimenkul alanlarında faaliyet gösteren iş adamı Cavit Çağlar tarafından kurulmuş ve 1999 yılında Doğuş Holding'e satımıştır. 2016 yılı sonu itibariyle Doğuş Holding, medyanın yanı sıra, finans, otomotiv, inşaat, medya, turizm ve hizmetler, gayrimenkul, enerji ve yeme içme sektörlerinde 300'den fazla şirketin sahibidir ${ }^{6}$. 2018 yılı Mart ayının sonlarında iktidara yakınlığı ile tanınan Demirören Grubu'na satılan Cnn Türk, 1999 yılında Doğan Medya Grubu ile ABD menşeili Time Warner şirketinin ortak girişimi ile kurulmuştur. Uzun yıllar Türkiye'de hem nicelik hem de nitelik bağlamında en büyük ve etkili medya grubu olan Doğan Yayın Grubu bünyesinde bulunan kanalın, çalışmanın yürütüldügü dönemde - diğer kanallarla karşılaştııılığında - en geniş konuk yelpazesine sahip kanal olduğu saptanmıştır. Habertürk TV, 2001 yılında gazeteci Ufuk Güldemir tarafından kurulmuştur. 2007'de Ciner Holding tarafından satın alınan kanal, madencilik, enerji, cam, kimyasallar, denizcilik, turizm ve ticaret sektörlerinde faaliyet gösteren holdingin medya grubunun ilk faaliyete geçen yayın kuruluşu olmuştur. Çalışmanın yapıldığı dönem itibariyle Ciner Yayın Holding bünyesinde Habertürk TV'nin yanı sıra Show TV, Bloomberg HT kanallarının yanısıra Habertürk Gazetesi, matbaa şirketi ve yapım şirketi de bulunmaktadır.

6 https://www.dogusgrubu.com.tr/tr/hakkimizda (Erişim tarihi: 09.04.2017) 
Çalışmanın yürütüldüğü dönemde izlenme oranı olarak bu üç kanalla boy ölçüşen bir diğer haber kanalı olan A Haber, bu çalışmanın kapsamı dışında tutulmuştur. 2011 yılında, o dönem başbakan olan Recep Tayyip Erdoğan'a yakınlığıyla tanınan ve Erdoğan'ın damadı Berat Albayrak'ın genel müdürlük görevini üstlendiği Çalık Holding'in sahibi Ahmet Çalık tarafından kurulan kanal, daha sonra el değiştirse de iktidarla ilişkileri yakın bir diğer grup olan Kalyon Grup'a bağı Zirve Holding'e satılmıştır. Kanal Sınır Tanımayan Gazeteciler Örgütü ile Bianet Bağımsız Illetişim Ağı işbirliğiyle hazırlanan Medya Sahipliği gözlem Raporu'nda "partizan bir TV kanalı" olarak sınıflandırılmaktadır7. Bu nedenle, bu kanaldaki programlar araştırmada kapsam dışında tutulmuştur.

Çalışmada ikincil kaynakların sentezlenmesinin yanı sıra, araştırmanın odağında yer alan üç haber kanalından haberciler, bu kanallarda yayınlanan programa katılan kanaat teknisyenleri ve bir süre öncesine kadar haber tartışma programlarına çağrıldığı halde artık davet almayan eski konuklarla görüşülmüştür. Mülakat yürütülen yirmi dört kişiden çoğu, görüşlerini açıklıkla ifade edebilmek için isimlerini ve kimliklerini açığa çıkarabilecek ayrıntıların kullanılmaması koşuluyla bu çalışmaya katılmışlardır. Bu nedenle, hem çalışmadaki bütünlüğü korumak, hem de ismi anılmayan kişilerin saptanmaması için görüşülen hiç kimsenin ismine bu çalışmada yer verilmemiştir.

12.10.2016 - 29.10.2016 tarihleri arasında gerçekleştirilen yirmi dört görüşme, yarı yapılandırımış görüşme tekniğine göre yürütülmüştür; yani temel sorular hazırlanmış, ancak konuşmanın seyrine göre mülakat sırasında sorular çeşitlendirilmiştir. Görüşme süreleri de 45 dakika ile 1,5 saat arasında değişkenlik göstermiştir. Derinlemesine görüşme yapılanlardan üçü, her biri farklı kanaldan olmak üzere, tartışma programı sunucularıdır ve yapılan alıntılarda bu kişiler "S" harfi ile tanımlanmışlardır. Tartışma programı editörü olarak, iki kanaldan iki kişi ile görüşülmüştür. Bu kişiler de "E" harfiyle anılmışlardır. Müdür ya da program müdürü olan iki kişi " $M$ ", prodüktör ve/veya konuk koordinatörü görevi yürüten üç farklı kanaldan üç kişi "P" harfiyle tanımlanmıştır. Görüşülen on kanaat teknisyeninin içinde aktif olarak gazetecilik yapan dört kişi vardır. Bunların yanı sıra üç akademisyen, bir emekli asker - araştırmacı, bir hukukçu ve bir araştırmacı - yazar ile de bu kapsamda görüşme yapıımıştır. Bu kişiler, kanaat teknisyeni tanımı uyarınca "K.T." kısaltmasıyla alıntılanmışlardır. Son olarak, çalışmada bir süre öncesine kadar sıklıkla ekran daveti alan ancak son dönemde "ekran ambargosuna" uğrayan dört kişiyle de görüşülmüştür. Bu eski stüdyo konukları da kısaca "E.K." olarak anılmıştır. İsimlerin ve katılımcıların kimliklerini ortaya çıkarabilecek ayrıntıların gizlenmesine rağmen sürekliliği ve konu bütünlüğünü mümkün olduğunca sağlayabilmek için görüşülen kişilere "S1", "E2", "K.T. 3" gibi numaralar verilmiştir ve aynı kişi, çalışmanın farklı bölümlerinde hep aynı numarayla alıntılanmıştır.

7 http://turkey.mom-rsf.org/tr/medya/detail/outlet/a-haber/ (Erişim tarihi: 21.10.2017). 


\section{Türkiye'de özel televizyon yayıncılığı ve tartışma programları}

Türkiye'de özel televizyon yayıncılı̆ı̆ının temelleri, bizzat dönemin başbakanı Turgut Özal'ın oğlu, Ahmet Özal'ın ortağı olduğu Liechtenstein'da kurulan Magic Box Inc. yayıncılık şirketi tarafından, 1989 yııında atıldı ve yıllar süren TRT tekelini kıran Magic Box Star 1 kanalı, 7 Mayıs 1990'da uydu üzerinden yayına geçti (Cankaya, 1997, s. 84). Bu süreçte, Türkiye'nin farklı yerlerindeki belediye başkanları, uydudan gelen yayınları karasal yayına çevirmek amacıyla, kendi bölgelerinde televizyon verici istasyonları kurup, izleyicileri ek bir yüke girmeden özel televizyon izleyebilme olanağına kavuşturdular (Çaplı, 2008, s. 132).

Yasal altyapının bulunmaması nedeniyle başta yurt dışından, uydu aracılığıyla, Uzan-Özal girişimi ile ve hükümetin desteğiyle "fiili durum" yaratılarak başlanan özel televizyon yayınları, kısa süre içinde yasal kılıfa sokuldu ve bu dönemde birbiri ardına kanallar kurulmaya başlandı. Star'ın yanına, üç yıl içinde Teleon, Show TV, TGRT, Kanal 6, Kanal D, HBB, ATV, Flash TV, Samanyolu TV, Kanal E, Cine 5, BRT gibi kanallar katıldı. Radyo ve televizyon yayıncılığında kamu tekelinin kaldırımasının üzerinden on yıl bile geçmeden, yaklaşık 1150 yerel ve ulusal radyo ile, 16'sı ulusal, 15'i bölgesel, 230'u yerel olmak üzere 261 televizyon kanalı yayına başlamıştı (Kaya, 2016, s. 259). Yüksek işletme giderleri nedeniyle belirli bir sermaye birikimi gerektiren özel televizyon sahipliği alanında Uzan, Özal gibi medya dışı alanlardan gelenleri, yukarıda sıralanan özelliklere sahip, daha önceden gazete sahibi olan işadamları izledi.

Daniel Hallin ve Paolo Mancini, farklı medya sistemlerini karşılaştırdıkları çalışmada, bir medya piyasasında sermayenin belli ellerde toplanmış olmasının, devletin medya patronları üzerindeki kontrolünün de artması anlamına geldiğini; bu durumda devlet desteği, sektörel düzenlemeler, kayırmacılık, çıkar ve güç birlikteliklerinin medya üzerinde etkili olduğu saptamasını yapmaktadırlar (Hallin ve Mancini, 2004, s. 48). Şirket sahiplerinin çıkarları doğrultusunda kurduğu siyasi bağlantılar, sahip oldukları medya kuruluşlarının yayınlarına da yansır. Bu iş adamları ellerindeki medya gücünü iktidar sahipleri ile bir pazarlık aracı olarak kullanır. Türkiye örneğinde de gazete sahipliğiyle başlayan böylesi bir yapı, 90'lı yıllarla birlikte özel televizyonların da bünyesinde yer aldığı medya gruplarına evrildi. Bu medya grupları, Ragıp Duran'a göre (2015, s. 22), büyük sanayi-mali-ticari holdinglerin "müştemilat şirketleri" görevini görmekte, Mustafa Sönmez'e göre ise (2014, s. 94), özellikle koalisyon yıllarında patronlara ellerindeki "gücü" iktidarla pazarık için kullanarak kayırmacıııktan faydalanma olanağı sağlamaktaydı. Bu çaıışmanın yürütüldügü 2016 yılı itibariyle, medya pazarında en büyük paya sahip beş medya grubunun (Doğan Grubu, Çalık Grubu, Doğuş Grubu, Ciner Grubu ve Çukurova Grubu) hemen hepsinin enerji, madencilik, finans, otomotiv, turizm ve inşaat gibi alanlarda büyük yatıımları bulunmaktaydı. Gülseren Adaklı (2014, s. 18), yukarıdaki tabloyu "ultra-çapraz bütünleşme" olarak adlandırmaktadır, yani medya şirketlerinin, holdinglerin medya dışı yatıımlarının bir tür garantörü gibi çalıştığını belirtmektedir. Başlarda haftada bir ya da birkaç kez yayınlanan tartışma 
programları, özellikle tematik haber kanallarının favori yapımları olarak gündemin belirlenmesinde sahip oldukları güçle birlikte, medya kuruluşu sahiplerinin iktidar odaklarıyla pazarlığının etkin aygıtları olarak işlevselleştirilmişlerdir.

Türkiye, tartışma programı formatı ile özel televizyonlardan önce, TRT ile tanışmıştır. Televizyon yayınlarının başlamasıyla birlikte, Batı' daki program formatları da Türkiye'ye uyarlanmıştır ki bunlardan biri de stüdyo haber tartışma programlarıdır. 1988-1989 yıllarında TRT'de, Ali Kırca tarafından sunulan "Açık Oturum" programı, ayda iki kez yayınlanmış ve yirmi bölüm sürmüştür ${ }^{8}$. Yine aynı yıllarda Uğur Dündar tarafından sunulan "Forum" da çok sayıda katılımcının görüşlerine ekranda yer verilen bir programdır ${ }^{9}$. Özel televizyonlar ile bu programların hem sayısı, hem de yayınlanma sıklıkları artmıştır. Rekabetin devreye girmesiyle birlikte bu programların sadece niceliği artırmakla kalmamış, diğer televizyon ürünlerine göre format konusunda büyük esnekliklere izin vermeyen bu tür programların içerikleri de zamanla değişmeye başlamıştır. Bülent Çaplı́nın (2008, s. 145), “özel televizyonculuğun kural tanımaz çocukluk çağı" olarak andığı ve Türkiye'nin "reyting, reality show, paparazzi ve talk show" gibi yabancı kavramlarla tanıştığı ilk dönemlerden itibaren tartışma programları arasında yaşanan reyting rekabeti, o güne kadar ekranlara davet edilmeyen ve/veya temsil olanağı bulamayan (TRT normlarına göre) daha "uç" isimlerin ekrana çıkarılmasına, üslûp ve içerik açısından daha geniş bir yelpazade söylemlerin televizyonlarda dillendirilmesine olanak sağlamıştır. Reha Muhtar tarafından 1992 yııında TRT'de sunulmaya başlanan ve sonra sırasıyla Star TV ve Show TV'de devam eden "Ateş Hattı", Mehmet Ali Birand ve Can Dündar tarafından 1993-1994 yıllarında 44 bölüm olarak yayınlanan "Çapraz Ateş", Hulki Cevizoğlu tarafından 1994 yılında HBB'de sunulmaya başlanan (ve birçok kanal gezdikten sonra kısa süre öncesine kadar Ulusal Kanal'da devam eden) "Ceviz Kabuğu", dönemin önde gelen tartışma programlarındandır. Türkiye'de en çok iz bırakan tartışma programı ise yaklaşık 20 yıl boyunca ekranlarda kalan, Ali Kırca'nın sunduğu "Siyaset Meydanı" olmuştur. İlk bölümü 6 Şubat 1994'te yayınlanan program, ${ }^{10}$ sunucusu Ali Kırca ile kanal kanal dolaşmış, zaman zaman süre, ve format değişikliklerine uğrasa da programın ikili yapısı hep korunmuştur. Bu yapı; meslek, sektör, siyasi parti, sivil toplum kuruluşu ve akademik dünyanın temsilcilerinin "uzmanlar" olarak konumlandırıldığı bir ana tartışma aksıyla, "halk meclisi" adı verilen ve "sokağın sesi" olarak sunulan katılımcılardan yer yer programın temposunu artırma, soruları çeşitlendirme ya da gündem içi başlıkları değiştirme noktasında faydalınılan bir "tribün" yapısı şeklinde açıklanabilir. Ancak, araştırmanın yürütüldüğü dönemde artık "siyaset meydanı formatı" da ortadan kalkmıştır. "Sokağın sesi" istisnai yayınlar dışında artık stüdyolarda yankılanmamaktadır ve bu tür programlar, özenle seçilmiş olan kanaat teknisyenlerinin söylemlerine teslim edilmiş durumdadır.

8 https://tr.wikipedia.org/wiki/A\%C3\%A7\%C4\%B1koturum_(TV_program\%C4\%B1 (Erişim tarihi: 29.03.2017)

9 https://tr.wikipedia.org/wiki/Forum_(TV_program\%C4\%B1) (Erişim tarihi: 29.03.2017).

10 https://tr.wikipedia.org/wiki/Siyaset_Meydan\%C4\%B1 (Erişim tarihi: 29.03.2017). 


\section{Ana akım haber kanallarındaki tartışma programları}

Türk Dil Kurumu'nun Türkçe karșılığını "altın saatler" olarak önerdiği "prime time" televizyonların en yüksek izlenme oranına sahip olduğu 20:00 - 23:00 saatlerini kapsamaktadır ve çalışmada konu edilen üç haber kanalı da "altın saatlerini" haber tartışma programlarıyla doldurmaktadırlar. Ben Bagdikian (2004, s. 6), uluslararası medya kartelleri arasındaki rekabetin, aslında bu kurumların ürünlerinin farklılaşmasına değil, tersine benzeşmesine yol açtığını belirtmekte ve ürettikleri içeriklerin aynı olduğu saptamasını yapmaktadır. Çok daha küçük ölçekte ancak benzer bir eğilim Türkiye'de de ortaya çıkmaktadır; haber kanalları birbirlerini, "prime time" kanalları kendi rakiplerini, spor kanalları mümkün olduğunca rakiplerinin yayın akışlarını kopyalamaya çalışmaktadır. Bourdieu'ye göre böylesi bir durum gazetecilik alanının tipik özelliklerindendir. Fransız düşünür çalışmasında (2000, s. 27-28) atlatma haber, yayın, program, konuk vs. kovalanmasının dayattığı baskıya dikkat çekmekte ve bunun için sürekli "rakipler ne yapıyor?" sorusunun gündeme geldiğine dikkat çekmektedir. Bourdieu, böylesi bir "rekabet" ortamında, bir noktadan sonra karşılıklı kopya çekmelerin başladığını ve "özelin, başka yerde, daha başka alanlarda, özgünlük ve tekillik üreten aranışının" tek biçimlilik ve sıradanlığa ulaştığını belirmektedir. Türkiye'deki haber kanallarında da, ele alınan dönemde, dikkat çekici bir program akışı benzerliği vardır. Çalışmada incelenen iki haftalık dilimde NTV, CNN Türk ve Habertürk'te akşam kuşaklarında yayınlanan tartışma programlarına ayrılan süre, üç kanalda yaklaşık toplam 78 saattir. Yine anılan dönemde, NTV her akşam ortalama 113 dakikasını, Habertürk, 162 dakikasını, CNN Türk ise 235 dakikasını bu programlara ayırmıştır.

Görüşme yürütülen medya çalışanlarının büyük bir bölümü, çoğu programın izleyiciler için bilgilendirici olmaktan uzak olduğunu belirtmiş, aslında kendilerinin de toplumu bilgilendirmek gibi bir kaygıyı her zaman taşımadıklarını vurgulamışlardır. Buralarda - bilgi üretilmesi bir yana - çoğu zaman yeni söylemlerin de gündeme gelmediğini, saptamak mümkündür:

"Zaten elli tane adamın, döne döne aynı şeyleri konuştuğu bir yerde, ne kadar yeni bir bilgi olabilir, bu ayrı bir tartışma konusu. Şu olabilir; bir şey olup bitiyor bizim de bununla ilgili herkesin kişisel bir görüşü var. Herkes kendi gibi düşünen insanlarla az çok aynı ortamlarda gün içinde beraber ama akşam bir tartışma programını açtığınızda sizinle aynı düşünmeyen bir insanla sizinle aynı düşünen bir insanın tartışmasını izlediğinizde belki yeni bir şey öğrenmiyorsunuz ama kendi savunduğunuz şey ile ilgili belki emin olmadığınız boşlukları dolduruyorsunuz 'Aa evet ya adam tam benim dediğim şeyi söylüyor'... Bundan emin oluyorsunuz ya da karşıt görüş, sizinle aynı düşünen insanı çürüttüğünde 'böyle düşünmemiştim, bu boyutu da olabilir' hissi gelebilir. Belki bilgilendirici değil, ama inandığımız ve düşündügümüz şeylerin sağlaması ve zıttını duymak anlamında faydalı olabilir" (M1).

"Bunun bir şov sahnesi olduğunu izleyici kaçırıyor. 'Açacağım ve tüm gerçekleri öğreneceğim' beklentisinde. Bunu yapamazsın. Nihayetinde bir işyeri burası. Sonuçta biz, her gün bu yayınları yapmak zorundayız. Her gün bu yayınları, bu sıkıcı konuları, çözemeyeceğimizi bildiğimiz Kürt sorununu yıllardır konuşuyoruz. Demek ki bizimle çözülecek bir şey değil yani. Orada sadece farklı bir perspektif 
görebilirsin. Olayın çözümünü orada bulamazsın ki arkadaş" (P3).

Pierre Bourdieu $(2000,23)$, televizyonun gösterilmesi gerekenden daha başka şeyler göstererek, ya da gösterilmesi gerekeni gösterirken, bunu göstermeyecek ya da anlamsızlaştıracak bir tarzda yaparak, ya da onu gerçekle hiçbir şekilde uyuşmayan bir anlam kazanacak tarzda kurarak gizleyebildiğini belirtmektedir. Dolayısıyla bu programların bir konuyu gündem haline getirirken diğerlerini gizleyip gizlemediği, yanıtlanması gereken bir diğer sorudur. Her üç kanalda da yayına çağırılan deneyimli gazeteci bir kanaat teknisyeni, ana akım medyada artık "neyin üzerine gidileceği" tartışmasından çok "nelerin gündeme alınamayacağı" tartışmasının olduğunu ifade etmekte, haber tartışma programlarını da bu yaklaşımla tasarlanan programlar olduğunu ifade etmektedir:

“... Tartışmama üzerine kurulu. 'Tartışalım, bir şeyler konuşalım ama eleştiri olmasın, fazla derine girmeyelim, ama işte oldu mu, oldu' programlarına döndü. Bir tanesi değil hepsi aşağı yukarı bakıyorsun öyle". (K.T.10)

Bir süre öncesine kadar programlara yoğun biçimde davet alan, hatta zaman zaman kendi programlarını da yapan ancak kendisiyle görüşmenin gerçekleştirildiği 19 Ekim 2016 tarihinde yapılan görüşmede, "2,5 yıldır medya kuruIuşlarından davet almadığını" belirten ve kariyerine ulusal ölçekte yayımlanan ve iktidara muhalif çizgisiyle tanınan bir gazetede köşe yazarı olarak devam eden bir başka isim ise gelinen noktada haber tartışma programlarını bir propaganda aracı olarak tanımlamaktadır:

"Bugün bu televizyonlardaki tartışmalar, bu kadar az sayıdaki tartışmacıyla katılımcıyla yapılıyorsa, bunun tek açıklaması vardır, bir kanaat mühendisliği yürütülüyor burada. Bunun adına ister dezenformasyon deyin, ister propaganda deyin, ister 'spin çalışması' deyin, ne derseniz deyin, burada bu izleyicinin zekası küçümsenerek yapılan bir çalışma. Bakıyorsunuz tartışma varmış gibi gözüksün diye seçilen üç ya da dört tane sözde muhalif isim çağrılıyor. Onlar da konuşuyorlar ve bir tartışma varmış gibi bir şey çıkıyor ortaya..." (E.K.1)

Gaye Tuchman, habercilikte gerçekliğin inşasını ele alan çalışmasında, "alıntıların", gazeteciler tarafından gerçeklik hissini pekiştirmek kullanıldığını belirtmektedir (Tuchman, 1978, s. 95). Televizyon programlarında da kanaat teknisyenleri birer "alıntı makinesi" gibi işle(til)mekte, gerçekliğin belli bir yönde üretilmesine katkı için devreye sokulmaktadır. Benzer bir yaklaşımla, Herman ve Chomsky de uzman görüşlerini egemen ideolojinin haber merkezindeki izdüşümü olarak nitelemekte ve eski ABD Dışişleri Bakanı Henry Kissinger'ın "uzmanlara" ilişkin tanımına işaret etmektedirler. Kissinger'a göre "uzmanlar", "genel kabul gören görüşleri taşıyan; bu uzlaşıyı üst düzeyde tanımlayan ve değerlendiren kişilerdir" (Kissinger'dan akt. Herman ve Chomsky, 1988, s. 23). Bu noktada 2016 yııında Türkiye'de gündem belirlemenin önemli aygıtları olan haber kanallarının, kanaat teknisyenlerini hangi filtre mekanizmalarını devreye sokarak ve ne gibi kriterlerden faydalanarak belirlediklerinin anlaşılması gerekmektedir. 


\section{Kanaat teknisyeni havuzunun derinliği}

Çalışma kapsamında her üç kanalda da iki haftaya yayılan süreçte, hafta içi kuşaklarda birden fazla stüdyo konuğunun ekrana taşındığı yirmi yedi farklı program kuşağı tespit edilmiştir. Bu programlarda Türkiye, ekranlarda toplam 4.700 dakika görüş bildiren, 77 farklı kanaat teknisyeni izlemiştir. Burada dikkat edilmesi gereken bir diğer nokta, bu 77 kişinin ekranda ne kadar göründügüdür. Yirmi yedi programda toplam katııımcı sayısı 109 kişidir ve bazı kişiler adeta "nöbetçi kanaat teknisyeni" olarak, birden çok kez ve kimi zaman da farklı kanallarda yayınlara davet edilmektedirler. Örneğin, bir hukukçu, üçü Habertürk, biri NTV ve biri de Cnn Türk olmak üzere beş farklı programa katılmış, bir kadın köşe yazarı da ikisi Habertürk, biri NTV, biri de CNN Türk olmak üzere dört farklı programa davet almıştır. Bir de belli kanala "abone" olan ve o kanalın birden çok programına katılan isimler vardır. Bir kamuoyu araştırma şirketi sahibi, CNN Türk'teki dokuz programın üçünde ekrana çıkmış, benzer şekilde, bir gazeteci de izlenen dönemde Habertürk'teki dokuz programın üçünde katılımcı olmuştur.

Öncelikle dikkat çekici bir veriyi bu noktada aktarmak gerekmektedir: Çalışma kapsamında görüşülen yirmi dört kişinin tamamı - ki aralarında mevcut iktidar partisine üye olanlar ve üye olmasalar da iktidarla yakın ilişkilerinin altını çizen isimler de vardır - "sizce Türkiye'deki tüm farklı sesler kendilerine ekranda yer bulabiliyor mu?" şeklindeki soruya olumsuz yanıt vermişlerdir. Bu çalışma kapsamında görüşmeyi önce kabul eden, yapılan mülakattan sonra görüşlerinin çalışmaya yansıtılmamasını isteyen bir program sunucusu ise daha sonra çalışma için farklı bir içerik sağlamış, düzenli olarak tuttuğu notlardan "artık ekrana çıkarılması mümkün olmayan konuklar" listesi derlemiştir. Bu listeye göre geçen altı yı içinde farklı zamanlarda kendi programlarında ekranda ağırladığı ve aralarında gazeteciler, hukukçular, siyasetçiler, siyaset bilimcilerin de olduğu kırk dokuz ismi "bugünkü şartlarda ekrana çıkarmasının artık mümkün olmadığını" belirtmektedir. Bu listedeki isimler arasında gözaltında bulunan ya da farklı davalar kapsamında tutuklu yargılanan gazeteci ve akademisyenler oldukça az sayıdadır. Listenin büyük bölümü, ana akım medya kuruluşlarından tasfiye edilen isimler ve her geçen gün aşağı çekilen "keskin konuşma çıtası"nın üzerinde kalan çok sayıda isimden oluşmaktadır. Yani çoğu isim, haklarında herhangi bir adli süreç işletiliyor olmasa da, ana akım yayın stüdyolarına artık davet edilmemektedir. Bir program yapımcısı ile uzun yıllardır ekranda haber tartışma programları moderatörlüğü yapan bir sunucu bu durumu sırasıyla şöyle aktarmaktadırlar:

"Havuz her bir olayla 'bir tık' daraldı, öyle söyleyeyim. Şöyle işte; 17-25'te 'bir tık' daraldı. Ondan sonra, 15 Temmuz'da daraldı. Aralarda Kürt meselesiyle ilgili, 1 Kasım seçimleriyle... Böyle her bir merhalede, yıl içinde, 'tık, tık daraldı' açıkçası. Dediğim gibi, kendi kendine de bu havuzdan çıkanlar oldu: 'Ben artık böyle saçma tartışmalara gelmek istemiyorum' diyenler de oldu. Tartışmaların anlamsız olduğuna inananlar da oldu. Çeşitli sebeplerle bu havuz gitgide küçüldü". (M1)

"7 Haziran seçimlerinden önce (2015) 'ya 2 sene önce kimleri çıkarabiliyorduk' diyordum. 7 Haziran'dan sonra, şu anda şimdi böyle HDP'nin h'sini, Kürt 
konusunun k'sini hükümetin eleştirilebildiği, askerin tartışılabildiği bir programı düşünemiyorum bile. Yüzde seksen değişti. 7 Haziran'dan öncesine göre, yüzde yüz değişmiş" (S1)

Sektöre göreli olarak daha geç girmiş ve yukarıda alıntılanan mevkidaşından çok daha kısa süredir tartışma programı sunuculuğu yapmakta olan bir başka isim de benzeri sorunlara işaret etmektedir:

"Çıkarabileceğim o kadar az kişi var ki; 20-30 kişi etrafında 4 gün öğütüyoruz. Önceki hafta Kezban Hatemi'yi aldım, dün ... (bir diğer sunucu) da aramış. Yani 14 günde biz hukukçu listemizi tükettik. Hem seyircinin tanıdığı isimleri almak ve risk almamak için daraldı havuz". (S2)

Görüşmeler sırasında, bazı medya çalışanları da uzman havuzunun aslında kişi sayısı değil, söylem ve katıımcı çeşitliliği açılarından sığlaştığını belirtmişlerdir. Bir program editörü ve üst düzey bir kanal çalışanı, mevcut durumun konjonktürle ilgisine sırasıyla şöyle değinmektedirler :

"Havuz daralmıyor da genişlemiyor da. Sürekli gidenler olduğu gibi, yerlerine gelenler de oluyor. Ergenekon, Balyoz sürecinde bağlanılanlara ve bir de şimdikilere bakın. Birileri gitmiş, yerlerine birileri gelmiş. Yarın bunlar da giderse yerlerine başkaları gelecek. Siyasi konjonktür bazı insanları dışarı itiyor. Bazı insanları sistemin içine çekiyor. Barış süreci döneminde yine bir kanalda editörlük yapıyordum. Orada kanala çağırdığım konukların hiçbirini şimdi çağıramam". (E1)

"Ana akım perspektifinden bağımsız bir şey değil aslında. O da şu; ana akım siyaset, ana akımın çerçevesinin dışında kalanlar... Bu göreceli ve değișen bir şey, dinamik. Çünkü o çerçeve sabit değil, o çerçeve ilerlediği için ortasında olan köşesine de geçebilir... Bu kadrajı kim belirliyor? Tamamen yine konjonktür belirliyor. Çünkü konjonktürdeki her türlü oylama, bir seçim sonucu ve bu seçim sonucunun yansımaları, bu çerçevenin genişlemesine ve daralmasına sebep oluyor". (M2)

Görüşülen medya çalışanları, kanaat teknisyeni havuzlarının daralmasının bir nedeni olarak da siyasi gerilim ve kutuplaşmadan dolayı çok sayıda ismin ekrana çıkmaktan vazgeçmesi ya da ilk kez davet götürülen bazı isimlerin, yukarıda anılan nedenlerle tekliflerini reddetmeleri olduğunu aktarmaktadırlar. Bu "endişeli" grupta başı çeken meslek grubu ise akademisyenlerdir:

"Telefon defterim daraldı. Yeni isim yaratmak artık güç. Hedef olmaktan çekindiği için çıkmak istemeyenler de oluyor: 'Şimdi içimdekini söyleyeceğim, o da bana döner' diyenler var". (P1)

"Siyasi görüşüne göre kaygısı farklı. Muhalifse 'aman üniversiteden atıırım' diyor, 'başıma iş gelir' diyor, 'soruşturma açılır, tutuklanırım'.. Yani korkular... O öyle gidiyor. Diğer tarafta da hükümet tarafında da çok savunamayacağı şeyler var diyelim ki hükümetin yaptığı, ama yayına çıkarsa bunu savunmak zorunda, ama bunun altını doldurmayacağını düşünüyor..." (M1)

"Üniversite hocaları eskisi kadar yayına çıkma konusunda istekli değiller. Bizim ekranlarımızda söyledikleri bir laf ertesi gün, soruşturma, tutuklama ve gözaltı olarak kendilerine dönebiliyor. Ya da akademiden dışlanabiliyorlar". (S1)

Medya çalışanları, programlarını birikmiş bir simgesel sermayeye sahip 
görmekte ve risk almaktan kaçınmaktadırlar (Darras, 2005, s. 165). İki kanalda, yıllardır konuk koordinatörlüğü/prodüktörlük yapan çalışanlara göre sürekli güncellenen kanaat teknisyeni listeleri, risk faktörünü minimize etmek üzerine kurgulanmakta; kanallar tercihini yumuşak ton seçenlerden yana kullanmaktadır. Bir alanda bazı dilsel ürünler diğerlerinden daha kıymetlidir ve Thompson'a göre (2013, s.18), konuşmacıların yetkinliği işte tam da içinde yer aldıkları piyasanın (alanın) neyi, ne kadar kıymetlendirdiğini bilmektir. Bu yetkinlik her zaman bir doğruyu en etkili şekilde söylemeyi değil, ancak güncel koşullar çerçevesinde "uygun" bir üslupla dile getirmeyi de gerektirmektedir. Üstelik bir kişinin söylem piyasasındaki yeri salt stüdyodaki performansı ile değil, aynı zamanda diğer mecralardaki üretim ve paylaşımlarıyla da ölçülmektedir:

"O gün yazdığı yazı, bir gün önce çıktığı bir programda dile getirdiği fikir gibi şeyler; hepsi belirleyici. Hükümetle arasının nasıl olduğu, yazdığı yazı nedeniyle birilerine dokunup dokunmadığı, akademisyense bulunması istenilmeyen bir toplantıda bulunması... Bunlar hepsi dengeleri değiştiriyor... Bir de taraf olduğu yönde çok altını çizenlerden ziyade '-mış gibi' yapanlar tarafındayız. '-Mış gibi' yapmayı seviyoruz". (P1)

"Yeni insanlara biraz güvenimiz yok. Şahsi kanaatimi söylüyorum; yeni bir insanın canlı yayında ne söyleyeceği kestiremiyorsunuz. Hele ki şöyle bir siyasi konjonktürde işin ucunun dokunup dokunmayacağını bilemiyorsunuz. Öyle bir mesuliyeti kabul edemiyorsunuz bir yerde...". (P2)

Görüşülen medya çalışanları kanaat teknisyeni seçimi yapmak ve gerekiyorsa yeni isimleri belirlemek için program müdürü / program editörü, konuk koordinatörü / prodüktör ve sunucu arasında bir diyalogun olduğunu ve yeni isimlerin yöneticilere danışıldığını belirtmektedirler. İlk kez çıkacak bir ismin program müdürü, hatta haber koordinatörü ve gerektiğinde genel yayın yönetmeninin onayı olmadan ekrana davet edilmesi söz konusu değildir.

Haber merkezi hiyerarşisinde, bir editör ve prodüktörün yeni işe başladığı haber merkezinde "uygun" konukların kim olduğunu öğrenmesi zaman alır, ancak bu işin önemli bir boyutudur (Louw, 2010, s. 64). Bu süreç, salt kıdemli çalışanların telefon rehberini zamanla kopyalamakla olmaz; aynı zamanda benzer yayın politikasına sahip medya kuruluşlarının muhabir ve editörleri arasında da sürekli karşılıklı konuk numaraları değiş tokuş edilmektedir. Kanallar arası "konuk takası" oldukça sık karşılaşılan bir durumdur. Bu sadece sığlaşan bir kanaat teknisyeni havuzundan seçim yapma güçlüğünün sonucu oluşan bir durum değil, aynı zamanda kendi programına siyasi meşruiyet katma çabasının da bir ürünüdür. Farklı iki kanaldan üst düzey program yöneticileri ve iki farklı programın prodüktörü/konuk koordinatörü ve editörü bu konudaki deneyimlerini sırayla şöyle açıklamaktadırlar:

"Kanallar arasında adı konmamış bir şey var. Gerek konunun, gerekse konuğun meşruiyetinin öbür kanalda olup olmaması üzerinden kuruluyor... işte o (kanal) bile aldıysa. Böylesi bir şey... Tabii bunun esas piri var: 'A Haber almışsa gözün kapalı al sorma bile!'.. 'A Haber aldıysa, TV Net aldıysa gözün kapalı al', psikolojik ortamı bu; realite, pratik bölümü değil. O da kendi içinde ayrışıyor. Onların alıp senin alamayacağın isimler var. Çünkü bu işin artık kıvrımları ve nüansları var. O kadar da değil, eşiği var". (M2) 
"Diğer kanallara katılmış olanlara bakıyorum. Bizim akşamları çalışan bir arkadaşımız var. O bize her gün, her akşam bizim yayın saatlerimizde karşı ekranlarımızda kimlerin olduğunu not ediyor isim isim. Sonra biz onlara bakıyoruz, dinliyoruz ve beğenirsek kendimiz de deniyoruz. Belki önce bültenlerde öneriyoruz... Ben de tartışma programlarında gördüğüm isimleri öyle yapıyorum". (P2)

"Konukları genelde kanallar birbirinden çalıyor. '... aldıysa, biz de alırı' diye alıyor... Çoğu da aslında 'googlelanıyor'. Bakıyoruz ne demiş diye, 'oo bak bu söylediği çok tehlikeli' diye" (E1).

Çalışma kapsamında yapılan görüşmelerde de siyasilerin medya üzerindeki doğrudan etkisi üzerine saptamalarda bulunulmuştur. Üstelik talepler salt iktidardan değil, tespit edildiği kadarıyla siyasetin diğer aktörlerinden de gelmekte, hatta bu süreci içselleştiren bazı orta seviye (editör, sunucu, konuk koordinatörü vd.) medya çalışanları da, siyasetçilerle aralarında doğrudan bir iletişim kanalını açık tutmaktadırlar. :

"Bir isimle ilgili, kafamızda soru işareti varsa (hükümet ya da 'saraydaki') danışmanlara soruyoruz. Bazen de direk danışman alarak kafamızın rahat etmesini sağlıyoruz. Mesela benim TRT'de görüp sonra takip edip, sonra ulaştığım bir akademisyen var. 2 kez çıkardıktan sonra 3. kez çıkacağını Twitter'dan duyurdu; 'akşam şu kanaldayım' diye. Bunun üzerine Cumhurbaşkanlığı kaynakları, bizi arayarak o ismi almamamız gerektiğini, onun çok 'kripto' olduğunu söyledi. O zaman siliyorsun ve sorunun çözülmüş oluyor". (P1)

"Ben örneğin MHP'den birisini yayına almak istediğimde ... var basınla ilgilenen, onu arıyorum 'şu kişiyi yayına davet etmek istiyorum' diyorum, parti içi disiplin var bir de, o kişiyle konuşuyor. Ben tüm partilerden bana 'sizi temsil edebilecek akademisyen, köşe yazarı ismi verin' dedim. Listeler de aldık zaman zaman. Mesela bir siyasi parti temsilcisi 'o isim iyi anlatamadı' demişti, biz de elemeye gidebiliyoruz, onlar da yapabiliyor" (S3).

\section{Kanaat teknisyenleri: Hızlı düşünen, her konuyu konuşan “yeni entelektüeller"}

Pierre Bourdieu'ye göre TV'lerde boy gösteren uzmanlar, "çağırılabilir insanlardır, iyi bir bileşim oluşturacakları, size güçlük yaratmayacakları, olay çıkarmayacakları bilinir; üstelik bolca hiç güçlük çekmeden konuşurlar" (Bourdieu, 2000 , 40). Ekranlara çıkmaya başlayan ve düzenli konuklar haline gelenler, mesleklerinden bağımsız halde televizyonun gösteri dünyasının aktörleri haline gelmekte ve gazetecilik alanının içinde yer alan "oyun stratejilerini" benimsemeye başlamaktadırlar. Haber tartışma programlarından sorumlu üst düzey bir isim bu dönüşümü şöyle anlatmaktadır:

"Konuk denilen kişinin de mesleğine olursa olsun, aynı isimleri sık sık çıkardığımız için, onun bir 'profesyonelleşmesi' meselesi var. Niye çağırıldığını biliyor... Kendisinden ne beklendiğini biliyor ve bunun ona deklare edilmesine gerek yok. Çünkü reklam arasında veya program sonrasında performansını soruyor zaten 
size. 'Benden bekleneni yapılabildim mi?'yi uygun bir dille soruyor". (M2)

Medya çalışanları ile yapılan mülakatlarda "sizce iyi ve kötü/zayıf konuk kimdir?" şeklindeki soruya verilen yanıtların neredeyse tamamında "ekran performansı" tanımı devreye sokulmaktadır. Öyle ki performans, birçok durumda bilgi birikiminden daha çok tercih edilen bir özellik olarak anılmakta, bazı kanaat teknisyenlerinden "o bizim yıldız ismimiz" şeklinde bahsedilmektedir. Programları hazırlayanlar, akademik ünvanlı ama söylemi gündelik dil seviyesinde tutan, uzun ve ağdalı çözümlemelerden kaçınan konuk peşindedirler:

"lyi stüdyo konuğu kimdir? Kısa konuşan, net konuşan, anlaşılır konuşan biraz hınzır biridir; şöyle yani biraz ironi yapabilecek, müstehzi konuşabilecek programın enerjisini yükseltebilecek... Arkaik bir tavır var: 'Bu konu 5 dakikada konuşulamaz', evet ama konuşacaksın, yani hiç konuşmamayı mı tercih edersin? O zaman gelme". (S2)

"Televizyon biraz şov yeriyse, burası da çok bilimsel gerçeklerin şey yapmadığı yer. Çok önemli şeyler söyleyebilir ama 'mıy mıy' işe yaramıyor çok. (P3)

"Derdini anlatabilecek mi? Karşı argüman geldiğinde, sinirlerine hakim olup kendini savunmaya devam edebilecek mi? Şimdi bir de akademik olarak bir şey anlatmakla, televizyonda anlatmak çok başka... Ekran performansı bu". (M1)

"Kafamızın bir tarafında iyi üniversite, iyi kurum, iyi titr... Yazdıkları enfes vs. ama televizyonculukta şöyle bir şey de var ne yazık ki, iyi konuşması da lazım. Kendisini iyi ifade edemiyorsa bizim için iyi bir şey değil. O yüzden kaynaklara bakıp nasıl bir konuşması olduğuna da bakıyoruz". (E2)

"Akademik çalışma çok detaylı bir çalışma. Dolayısıyla onu yapan çok heyecanlanıyor, onu en ince ayrıntısına kadar aktarmaya çalışıyor. Oysa seyirci dediğin, 6 dakika bile değil, maksimum 3-4 dakikada dikkati dağılan bir seyirciden bahsediyoruz... Hem ilgi çekici olacak, hem belagati kuvvetli olacak, hem enteresan olacak, hem çalışması kuvvetli olacak hem de bunu dinlenebilir hale getirecek". (S1)

Bourdieu'ya göre kanaat teknisyenleri, "buyur edilmiş fikirlerle" düşünmektedirler; yani, herkesçe kabul edilmiş olan, sıradan, kararlaştırılmış, ortak fikirlerle (2000, s. 34). Bu, hem medyanın acil taleplerine yanıt vermelerini sağlamakta, hem de değişen gündem başlıklarına dair uzmanlık gerektiren birçok farklı konuda kendi uzmanlık alanıymış gibi konuşabilmelerine olanak tanımaktadır. Görüşülen isimlerin çoğu, televizyon stüdyolarında yayına katıldıklarında "uzmanı olmadıkları konularda" konuşmak durumunda kaldıklarını belirtmişlerdir. Bazıları gündelik rutinlerini buna göre ayarladıklarını, "her an bir konuda yayına çağrılacakmış gibi ders çalıştıklarını" aktarmaktadırlar:

"Ben bulunduğum pozisyon sebebiyle zaten aktüaliteyi çok yakından takip eden bir insan olduğum için, aktüaliteyi takibi mecburen bu tartışmalar için de kurumsal hale getirdim, kendim açısından sürekli... Meseleyi takip ediyorum, nerede, ne var çünkü her an bir şey söylemek zorunda kalabilirim" (K.T. 5).

Aslında kariyerinin başından beri sosyoloji alanında çalışmalar yürüten bir akademisyen de her üç kanal tarafından da farklı zamanlarda, farklı gündem maddelerini "tartışmak" üzere ekrana çıkarılmaktadır: 
“... Çünkü zaman zaman şöyle bir eleştiri alıyorum: 'Hocam siz neymişsiniz! Her şeyi biliyorsunuz...'... Musul'u konuşuyoruz, başkanlık sistemini konuşuyoruz, terörü konuşuyoruz. Hangisinin uzmanı olacak bu adam? Hepsini takip etmesi gerekiyor. Sizi bu gündeme mahkûm eden programın yapımcısı, moderatörü, her kimse, adam böyle bir şeyi uygun buluyor kendi programı için... Şu şöyle bir sonuç yarattı yıllar içerisinde; beni zaman zaman uluslararası ilişkiler uzmanı gibi görüp, ya da sanıp toplantılara, konferanslara falan davet edenler oluyor artık". (K.T. 5)

Çalışma kapsamında NTV, CNN Türk ve Habertürk kanallarındaki iki haftalık tartışma programı katııımcılarının dağılımına bakıldığında toplam 109 kanaat teknisyeni görünümünde, gazeteciler 33 görünümle ilk sıradadır. Onları 21 katıIımla hukukçular $(\% 19,3), 17$ katılımla akademisyenler (\%15,6), 14 katılımla siyasetçiler (\%13), 10 katıımla emekli askerler izlemekte (\%9,2), altıncı sırada ise sekiz katılımla $(\% 7,3)$ kamuoyu araştırma şirketi yöneticileri gelmektedir. Kalan yaklaşık yüzde beş oranındaki koltuk ise (toplam 6 katılım), düşünce kuruluşu temsilcileri, yazar ve araştırmacılar arasında paylaştıııımıştır.

Şekil: 1. 24 Ekim - 4 Kasım 2016 arasında NTV, Cnn Türk ve Habertürk'e çıkan kanaat teknisyenlerinin mesleki dağılımı

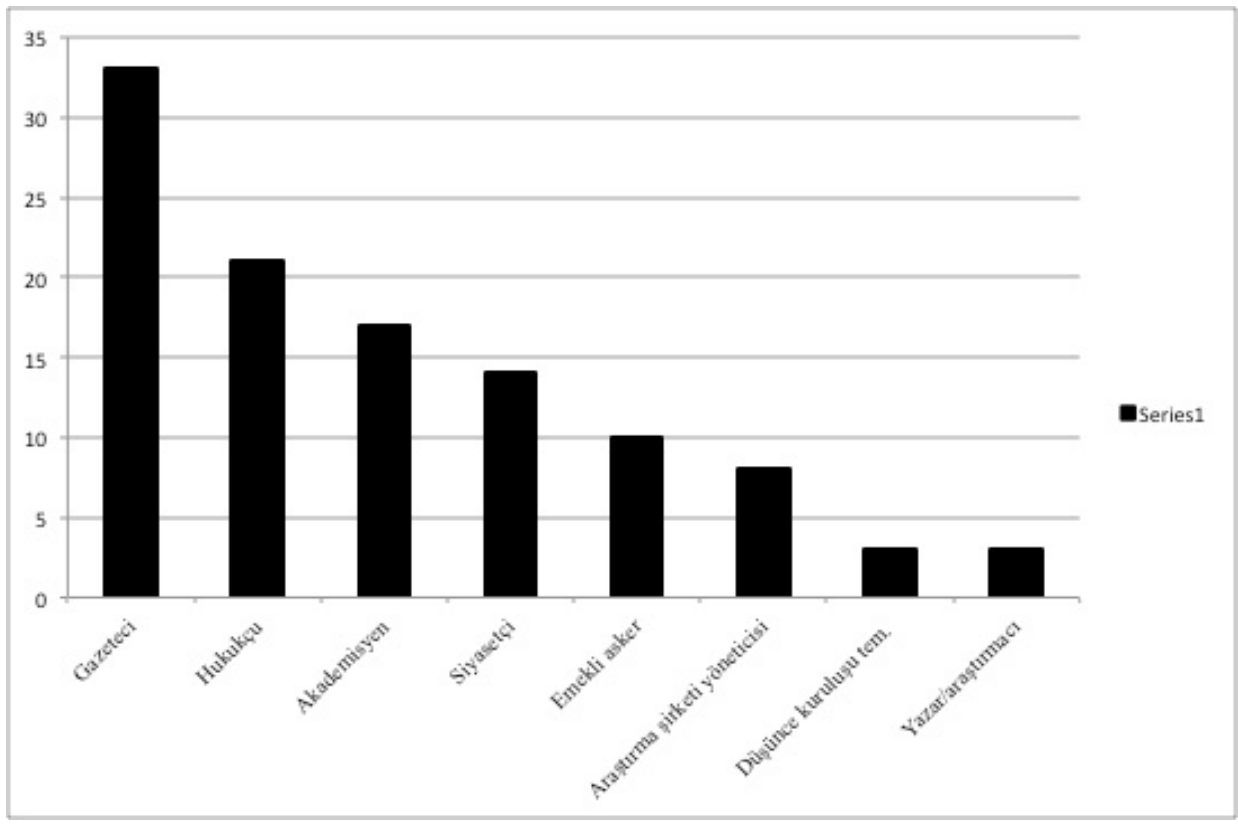

Eric Louw'a göre, gazetecilerin ekran hakimiyeti kendileri hakkında, nesnel, gündem belirleyen kişiler oldukları yönündeki fanteziden kaynaklanmaktadır. Bu durumda bir gazeteci diğerini "kâhin uzman" konumuna yerleştirmekte ve böylece "kâhin gazetecilerden" bazıları yıldızlaşmaya başlamaktadırlar (Louw, 2010, s. 
65). Ancak unutulmamalıdır ki gazetecilerin kehanetleri ağılıklı olarak siyasi kulislerden derleyebildikleri bilgiler ya da kendilerine sızdırılan haberler çerçevesinde olmaktadır. Michael Schudson, ABD'de gazetecilerin, Washington çizgisinden uzakta ve örneğin bir çatışmanın tarihi ya da bir siyasetin ahlakiliği üzerine yorum yapabilecek uzmanlara rağbet edilmediğini belirtir (Schudson, 2005, s. 220). Türkiye'de de çalışma yapılan dönemde, televizyondaki tartışma programlarına davet edilen gazeteciler arasında ana akımda çalışmayanların sayısının oldukça az olduğu dikkat çekmektedir. Dolayısıyla çoğu zaman gazeteci olan sunucu, siyasetin kulislerinden beslenen bir diğer gazeteciyi yayına çağırarak aslında siyasetin şekillendirdiği ve gün boyu gazete, internet siteleri ve haber bültenlerinde işlenen gündemin yeniden üretilmesini sağlamaktadır.

\section{Tartışma programlarında siyasetin temsili}

Çalışma kapsamında değerlendirilen her üç kanalın iki hafta boyunca yayınladıkları haber tartışma programlarında siyasetçiler, gazeteci, hukukçu ve akademisyenlerden sonra dördüncü sırada görünürlüğe sahiptirler. Toplam 109 konuk görünürlügünün içinde, 14 siyasetçi görünürlüğü tespit edilmiştir. Kanallar siyaseti, siyaset dışı gözüken aktörlerle konuşmayı tercih ederken, doğrudan bir siyasi parti içinde aktif olarak görev almış olan isimlerin ekranda niceliksel kıyaslamaya tabi tutulup kanalın objektiflik ilüzyonunun dağılmaması hedeflenmektedir. Ancak aşağıdaki grafikte de görüleceği üzere, incelenen dönemde zaten önemli bir nesnellik krizi söz konusudur. İki haftalık (24 Ekim - 4 Kasım 2016) süreçte üç kanalda 14 siyasetçi görünümü söz konusu olmasına rağmen TBMM'de üçüncü parti konumunda olan HDP'den hiç bir siyasetçi ekranda temsil olanağı bulamamıştır. Üstelik, 26 Ekim tarihinde Diyarbakır Büyükşehir Belediyesi eş başkanları, Gültan Kışanak ile Fırat Anlı gözaltına alınmış, bu iki isim 30 Ekim'de tutuklanmışlardır. Yine bu dönemde, 3 Kasım'ı, 4 Kasım'a bağlayan gece HDP'li milletvekillerine operasyon yapılmış ve aralarında eş genel başkanlar Selahattin Demirtaş ile Figen Yüksekdağ'ın da bulunduğu çok sayıda milletvekili gözaltına alınmıştır. 4 Kasım akşamı ise aralarında Demirtaş ve Yüksekdağ'ın bulunduğu 8 milletvekili tutuklanmıştır. Bahsi geçen ana akım haber kanallarında (birçok diğer kanalda olduğu gibi), 7 Haziran seçimleri sonrası düzenlenen Suruç saldırısı ve ardından Ceylanpınar'da iki polisin öldürülmesiyle birlikte çatışmasızlık döneminin son bulması ve iktidarın HDP'yi "terör örgütünün siyasi uzantısı" olarak tanımlamasının ardından HDP'liler ekrana davet edilmemeye başlanmış; 1 Kasım seçimleri sonrası bu tutum artık sorgulanamaz bir kural haline getirilmiştir. 
Şekil 2. Siyasi partilerin oy oranları ve 24 Ekim - 4 Kasım tarihleri arasında NTV, CNN Türk, Habertürk'teki tartışma programlarına katılan milletvekillerinin oransal dağılımı.

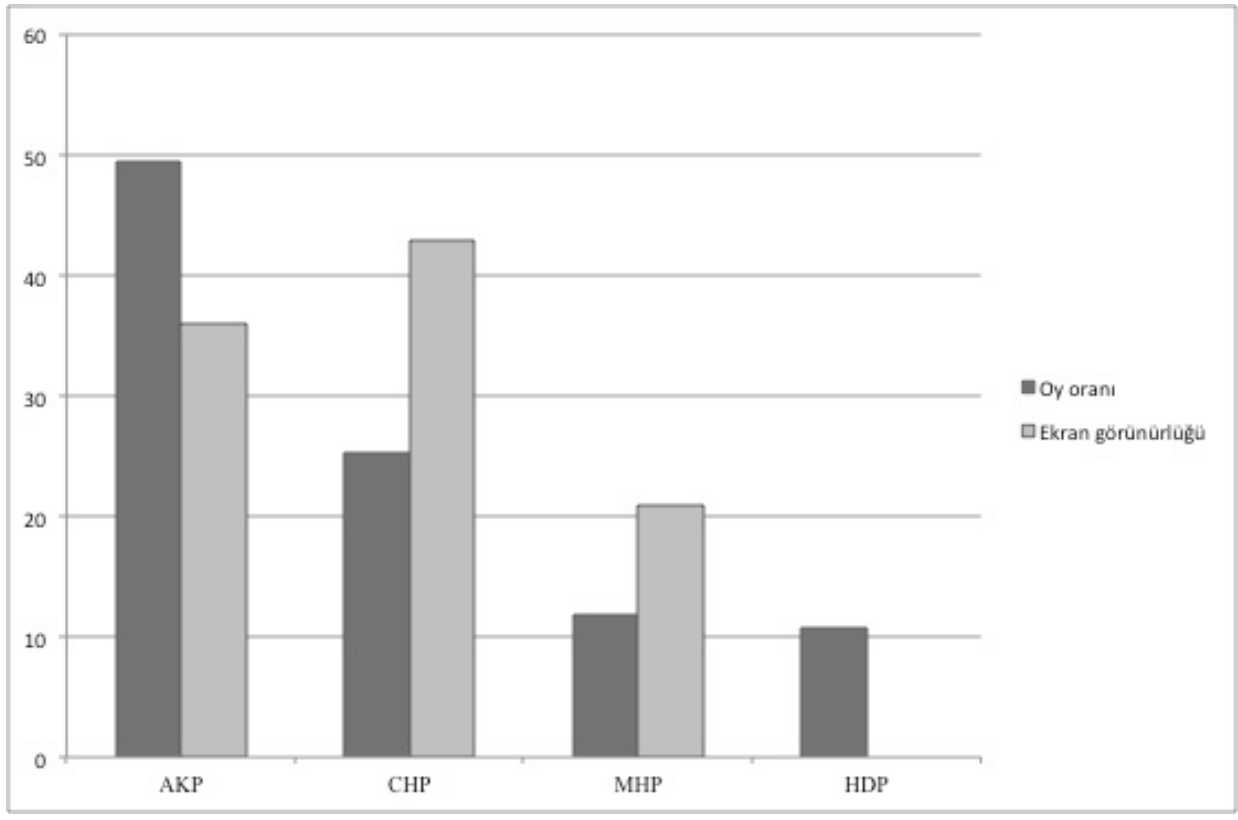

Yukarıdaki grafikte dikkat çeken bir diğer nokta, iktidar partisi AKP'nin 1 Kasım seçimlerinde aldığı oy oranı \%49,5 olmasına rağmen incelenen iki haftalık süreçteki tartışma programlarına katılım sağlayan AKP'li siyasetçi oranının CHP'den düşük olmasıdır. Bu, iki nedenden kaynaklanmaktadır: Birincisi, ana gündem maddeleri söz konusu olduğunda AKP ve MHP bir söylem birliği içindeyken, HDP'ye ekranda yer verilmeyerek "muhalif tavır" CHP'li vekillerden bekIenmiştir. Ayrıca, tartışma programlarında boy gösteren AKP'li milletvekillerinin sayısı CHP'lilere göre düşük olsa da söylem açığı iktidar çizgisinde görüş bildiren, gazeteci, akademisyen, hukukçu kanaat teknisyenlerinin yoğun katılımıyla kapatılmakta hatta çoğu zaman iktidar söylemi baskın hale gelmektedir. İki haftalık süre boyunca, tartışma programı ekranlarında boy gösteren; 33 gazeteci görünümünün 18 'i iktidar çizgisinde yorum yapan isimlere, 10'u iktidara muhalif görüşleriyle tanınan isimlere, beşi de hem iktidar, hem de muhalefete eleştirle yaklaşabilen isimler tarafından sağlanmıştır.

Bourdieu, "Dil ve simgesel iktidar" adlı kitabında, simgesel üretim sürecinde pazar dinamiklerinin sansür ve oto-sansür sürecini yönettiğini belirtmekte ve bu dinamiklerin "sadece bir şeyin nasıl söyleneceğini değil, neyin söylenip, neyin söylenemeyeceğini de yönettiğini" vurgulamaktadır (Bourdieu, 2013, s. 77). Bu çalışma kapsamında görüşülen ve "muhalefet kontenjanı" üzerinden tartışma programına davet edilen isimler de kullandıkları dile dikkat ettiklerini, yazılarında ya 
da akademik çalışmalarında kullandıkları ifadeleri ekranda, canlı yayınlarda kullanmaktan zaman zaman, kaçındıklarını ve tüm izleyicilerin anlayamaması pahasına yer yer daha ağdalı dil ve dolambaçlı anlatımlar tercih ettiklerini vurgulamışlardır:

“...Ben mutlaka düşündüğüm şeyi söylüyorum. Bazen öyle söylüyorum ki 100 kişiden 60'ı anlıyor. Mesela Cumhurbaşkanı'nın Irak Başbakanı ibadi'ye yükselen tonu içerideki tribünlere yönelik; bunu anlatmaya çalışırken 'Putin iktidara geldiğinden beri Rusya'ya düşman yaratarak ülke içindeki desteğini hep artırdı" dedim. Baktım sosyal medyaya 'biz böyle bir lider tanıyoruz' diye mesajlar geldi. Bunları anlatmanın bir yolunu bulmaya çalışıorum". (K.T. 3)

"... Ben eleştiri yaparken isimler üzerinden eleştiri yapmıyorum. Ben hiçbir zaman çıkıp 'bu Başbakan şöyledir, bu Başbakan kötüdür' veya 'bu Cumhurbaşkanı şöyle yapıyor" diye yazılarımda ve televizyon konuşmamda demiyorum. Ama bu iktidarın getirdiği, meselâ, 'bu proje okullar rezalettir, şöyle rezalettir' diye anlatıyorum..." (K.T. 10)

Bir süre öncesine kadar, tartışma programlarına yoğun olarak davet edilen, hattâ belirli bir ücret karşılığı bazı programların "sabit" konuğu olan kanaat teknisyenlerinden bu çalışma süresince ekran ambargosuna maruz kalmakta olan isimler ise dışlanmalarının en enemli nedeni olarak söylemleri ve konuları ele alış biçimlerini göstermektedirler:

“... Şöyle şeyler, 'biraz daha dikkat edersen seni daha sık çağırabiliriz'... Arkadaşça şeyler: 'Şuna dikkat et. Erdoğan'ı daha az zikret' gibi... Söylenmesi gerekeni söyledim. Kurgu yapmadım, isteseydim de yapamazdım. Çünkü hissettiğim, doğru olduğuna inandığım ne varsa söyledim. Üslup sert kaçmış mıdır? Olabilir." (E.K.2)

"...Muhalif koltuğunda oturanlar giderek şekil değiştiriyor. Daha önce kabul edilebilir olanlar yavaş yavaş bir noktadan sonra bu ortam keskinleştikçe kabul edilemez hâle geliyor. Bu süreç nereye kadar devam eder bilmiyorum ama ben ortada zaten çok ciddi muhalif ses falan görmüyorum". (E.K. 3)

Herman ve Chomsky (1988, s. 22), eleştirel kaynakların, sadece daha zor erişilebilir ve/veya iddialarını kanıtlamak gibi kendilerine yüklenen ek yüklerin ötesinde, birincil kaynakların "incitilmemesi" için de dışlandığını belirtmektedirler. Hükümet kaynakları, eleştirel yayın yapan kanallara farklı düzeylerde yaptırım uygulayabilmektedirler; resmi programlara akreditasyon kısıtlamasından, üst düzey siyasetçilerin o kanala çıkmamasına, kulis haberleri sızdırılırken o kanalın yok sayılmasına kadar, geniş bir yelpazede gerçekleştirilebilmektedir bu yaptırımlar. Ayrıca Türkiye'de son dönemde sıklıkla görüldügüü üzere kıymetli olarak addedilen kaynakların "o yayına çıkarsa ben çıkmam" şeklindeki taleplerine boyun eğilmekte, ya da sıra ile konuk alma şekli benimsenmekte ve böylece aslında bu "kaynaklar" salt programın içeriğine değil, biçimine de etki etmektedir.

\section{Tartışma programlarında toplumsal cinsiyet}

Her üç kanalın, haber tartışma programı yayınlarının iki haftalık takibi sonrası muhalefetin az ve/veya eksik temsilinin yanı sıra, kadınların yok denecek kadar az temsil edilmesi de dikkat çekmiştir. İki haftaya yayılan zaman diliminde 
yayınlanan saatler süren yirmi yedi farklı tartışma programından sadece dokuzuna kadın konuklar katılıştır. Toplam 77 farklı katıımcıdan, sadece beşi kadındır ve bu 77 kanaat teknisyeninin farklı programlarda ortaya koyduğu 109 görünümün, sadece dokuzu kadınlara aittir. Yayınlara katılanlardan, Habertürk Gazetesi yazarı Nihal Bengisu Karaca, dört farklı programda yer almıştır. Hukukçu, Kezban Hatemi, iki; Milliyet Gazetesi yazarı Nagehan Alçı, bir; akademisyen Elfin Tataroğlu, bir; gazeteci ve yazar Nur Batur da bir programa katılmıştır.

Pierre Bourdieu (2007, s. 266), "en radikal sansür, sahnede olmamaktır" der. Dolayısıyla temsil oranı; söz söyleme yerine erişim ve ikincil olarak da ifade zamanıyla ölçülen söz söylemeye erişim şansı gözetilince, kadınlara yönelik sansür görünür olmaktadır.

Şekil 3. 24 Ekim - 4 Kasım tarihleri arasında üç kanaldaki tartışma programlarında kadın ve erkeklerin ekrandaki görünürlüğü.

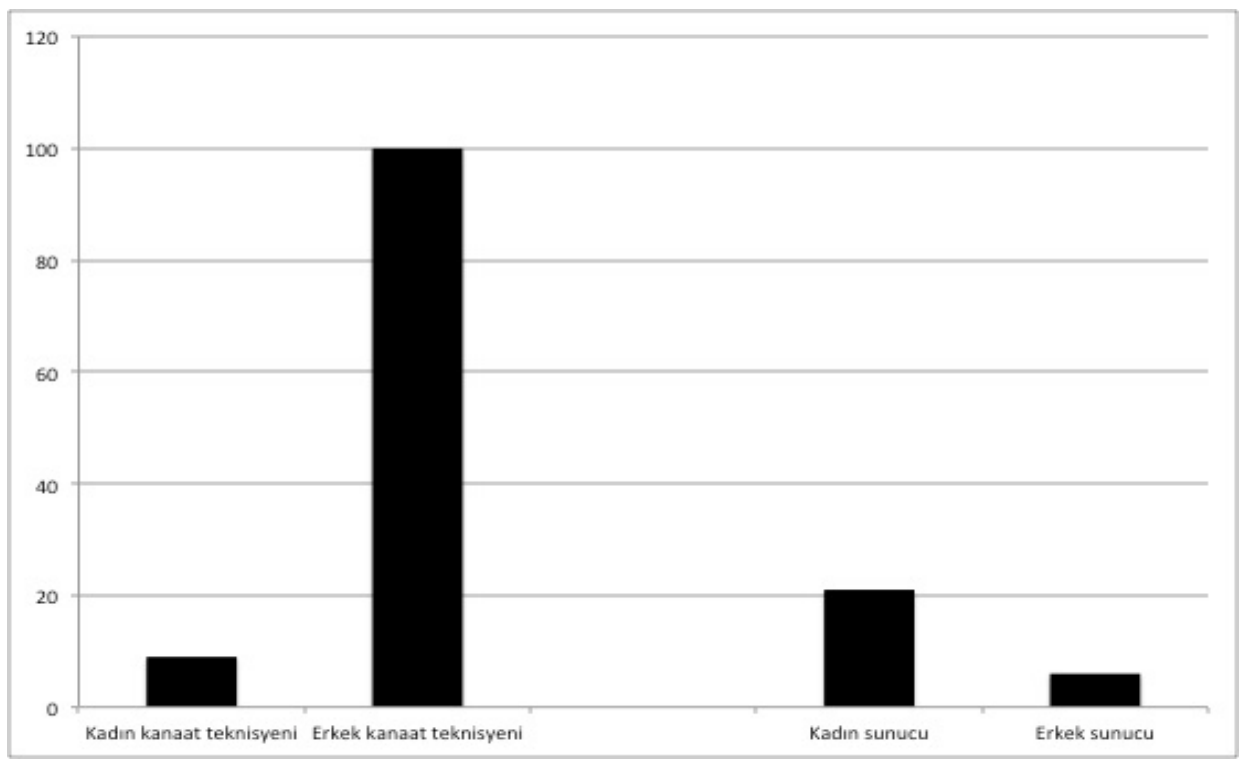

Toplumsal hayatın farklı katmanlarında vücut bulan cinsiyet eşitsizliği, medyaya da doğrudan yansımaktadır. John Fiske'e göre (1999, s. 284), kamusal alan erildir ve erkeklerin sayısal hakimiyetindedir. Haberler (ve haber programlar) işte bu kamusal alanla ilgilidir ve çoğunlukla erkek seyirciye göre hazırlanan ve kamusal alanın erilliğinden beslenen bir yapdadır.

Pierre Bourdieu'ye göre, cinsiyet bir özerk sistem değil, diğer kategorilere "sızan" ve etkileyen bir toplumsal kategoridir (Adkins, 2005, 6). Bu yaklaşıma göre, toplumsal cinsiyet üzerinden tesis edilen baskı, simgesel şiddetin bir izdü- 
şümüdür. Çünkü kadın-erkek olarak yapılan ve biyoloji devreye sokularak "normalleştirilen" cinsiyet ayrımı, sorgulanamaz bir "doksa" halinde, toplumsal olarak inşa edilen iktidar ilişkilerinin gerçek yüzünü örtmektedir (Moi, 1991, s. 1030). Bu yaklaşıma göre, eril düzenin gücü, iki süreci birarada toplamasından kaynaklanmaktadır: "Egemenlik ilişkisini, kendisi de doğallaştııımış bir toplumsal inşa olan biyolojik doğaya eklemleyerek meşrulaştırmak" (Bourdieu, 2001, s. 23). Bourdieu, mesleklerin toplumsal mantığının, simgesel baskının kurbanlarının, itaat, nezaket, uysallık, adanma ve kendini yadsıma "erdemlerine" göre biçilen ikincil görevleri makul bir biçimde yerine getirme üzerine kurulduğunu belirtmektedir (Bourdieu, 2001, s. 57). Programların gündemine taşınan, ulusal güvenlik, iç siyaset gibi konular eril alanın "uhdesinde" kabul edilmektedir. Ancak, her alanda toplumsal cinsiyet rollerine ilişkin benzer bir statükonun hakim olmadığı da bir gerçektir; örneğin, akademi, hukuk ve medyada kadınlar erkeklerle daha rekabetçi bir pozisyon içindeyken, siyaset alanı daha erkek egemen bir yapıdır; söz konusu olan emekli asker ve polislerin yer aldığı "güvenlik politikaları uzmanlığı" gibi bir alt kanaat teknisyeni grubuysa, Türkiye'deki mevcut işleyiş göz önüne alınınca bu kısım kadınlara neredeyse tamamen kapalı gibidir. Bu çalışma sırasında Türkiye'de gündemde olan "terörle mücadele", "sınır ötesi askeri operasyonlar" gibi konuların haber tartışma programlarında ele alınması kadınların zaten düşük olan temsiliyetini daha da aşağı çekmektedir. Ayrıca ana akım kanallar üzerindeki, kanal çalışanlarının da içselleştirdiği, siyasi baskılar ve siyaset dilinin her geçen gün muhafazakârlaşması da kadınların temsiliyetini azaltan bir diğer etkendir.

Incelenen zaman diliminde haber tartışma programlarında kadınların temsili göz önüne alınınca şöyle bir genellemeye varılabilir: Kadınlar ayakta, yani sunucu / moderatör masalarının başında, erkekler ise konuk koltuklarında oturur durumdadırlar. Bölümün başında sunulan grafikte (şekil 4.2.) görüleceği gibi, bu programlarda kadın konuk oranı erkeklere göre ne kadar düşükse kadın sunucu / moderatör oranı o kadar yüksektir. Kadınlar bu iki haftalık dönemde takip edilen 27 haber tartışma programının yirmisini sunmuş, kalan yedi program, erkekler tarafından sunulmuştur. Thornham'a göre (2007, s. 89), sunucu ve/veya moderatör konumundakiler, çoğu zaman burada toplumsal olarak belirlenmiş bir "kadın işlevi" taşımakta; farklı bir odağın elindeki iktidarın retoriğini süslemekte ve yumuşatmakta, ancak bir kadın gibi konuşmamaktadırlar. Yani, gerçekten iyi gazetecilik istisnaları hariç, stüdyodaki kadınlar eril söylemin göze hitap eden sunucusu konumunda tercih edilmektedirler.

\section{Sonuç}

Televizyon tartışma programları, zaten kanallarda sabit maaşı çalışan kadrolar tarafından üretildiği ve konukların büyük bölümüne herhangi bir ücret ödenmediği için yerine konulabilecek diğer bir çok program formatına göre, maliyeti oldukça düşük yapımlardır. Ancak burada dikkat edilmesi gereken, sadece bir kanalın ya da medya grubunun kısa dönem bütçesine yansıyan yapım maliyeti değil, o kanalın ya da medya grubunun sahibi olan holdingin diğer sektörlerdeki 
iş yapabilme olanaklarının artması ya da azalmasında medya grubunun ürettiği ürünlerin de önemli bir faktör olduğudur. Sermaye yapısındaki çapraz bütünleşme; yani farklı iş alanlarında faaliyet gösteren bir holdingin/grubun medyanın farkı alanlarında faaliyet gösteren bir medya grubunun sahibi olması, diğer birçok yayın aracında olduğu gibi televizyonlarda da haber ve bağlantılı programların içeriğine damga vurmaktadır. Dolayısıyla, sahibinden, yöneticisine, editöründen sunucusuna herkes, ürettikleri ürünün salt ekonomik maliyetini değil, ancak aynı zamanda siyasi maliyetini de göz önünde bulundurmaktadır.

15 Temmuz 2016'daki kanlı darbe girişimi sonrasındaki olağanüstü hal döneminde gazetecilik alanı da simgesel şiddetin hem nesnesi, hem de öznesi olarak yeniden tanımlanmakta, bu alanda etkili konumda var olmanın ya da üst düzey yöneticilik yapabilmenin ön koşulu, kültürel sermaye ya da eğitim sermayesi gibi geleneksel kazanımların ikinci plana düşmesiyle birlikte, siyasal sermaye olmaktadır. Mevcut ortamda, büyük sermaye sahipleri de orta ve uzun vadede var olma mücadeleleri sonucu, ellerindeki medya gruplarını, zaman zaman kendi kısa vade çıkarlarını örseleyebilecek ölçüde (yayıncılık faaliyetinden zarar etmek pahasına), iktidar ile ilişkilerine zarar vermeyecek şekilde, yeniden tasarlamışlardır. Rekabetin azaldığı ve medyanın, içeriğin zenginleştirilmesi için para harcamaya değer görülmediği böylesi bir ortamda, statükoyu yeniden üreten bir medya aracı olarak tasarlanan televizyon tartışma programları, içerik üretme krizindeki medya profesyonellerinin can simidi olmaktadır.

Ekrana davet edilen isimler konusunda ciddi bir kontrol mekanizması oluşturulmuştur ve ekrana ilk kez çıkarılacak, mevcut konuk listesi dışından isimler, istisnaî durumlar dışında, mutlaka haber merkezi yöneticisine ya da genel yayın yönetmenine onaylatılmaktadır. Nihai eşik bekçisi konumunda bu pozisyonlardaki isimler yer almaktadır. Belirli filtreleme mekanizmalarından geçirildikten sonra olsa dahi "sade vatandaşa" güncel konularda canlı yayında görüşünü bildirme olanağı tanıyan "Siyaset Meydanı formatı" terk edilmiş durumdadır. Halk tepkisi, sadece sunucu ve konukların sosyal medyayı kaynak göstererek o anki konjontüre göre "uç" ya da "sert" olarak değerlendirdikleri söylemleri hizaya çekmek, tekzip ettirmek vs. gibi saiklerle devreye sokulmak üzere araçsallaştırılmış bir statüko filtresi olarak kullanılmaktadır. Toplumsal ve siyasal yaşamdaki asimetri, programlara davet edilen kadınların oranlarından, siyasal parti temsillerine kadar stüdyolarda doğrudan yansımasını bulmaktadır. Görüşülen, tüm çalışanlar kendilerine otosansür uyguladıklarını farklı biçimlerde ifade etmektedirler.

Bu araştırmanın kapsadığı dönemde, televizyon tartışma programlarının, bağımsız bir habercilik faaliyetinin uzantısı olmaktan çok, ağırlıklı olarak mevcut hegemonya doğrultusunda, söylemlerin yeniden üretilerek toplumsal bir rıza üretimi aracı olarak işledikleri anlaşımaktadır. Kuruluşundan itibaren özel kanalların, bağlı bulundukları sermaye gruplarının çıkarları doğrultusunda ana akım medyanın tipik rıza imalâtı aygıtları olarak işlev üstlendiği ortadadır. Buralarda göreli olarak çok sesli bir yayıncılık anlayışının var olması, Türkiye'de gazetecilik alanı üzerinde- 
ki en etkili olan olan siyaset alanındaki gücün konsolidasyonuyla ters orantılıdır. Olağanüstü hal gibi kriz dönemleri, görüşülen medya çalışanları ve kanaat teknisyenlerinin ifadelerine göre söylem çeşitliliğinin en düşük seviyelere indiği anlara işaret etmektedir. Siyaset alanındaki bir dönüşümle birlikte sermaye gruplarının pazarlık güçlerinin tahkimatı sonucu böylesi bir çeşitliliğin artması beklenebilir. Ayrıca hegemonik ana akım medya düzenine karşı, her geçen gün ucuzlayan ve yaygınlaşan teknolojiler sayesinde serpilen yeni medya platformlarının da gazetecilik yapma iddia ve iradesini sürdürenler ile kanaatlerden çok bilgi üretimi çabasındaki aktörlere ürünlerini daha geniş kesimlerle paylaşabilme ve böylece medya alanını demokratikleştirme olanağı sağlaması söz konusu olabilecektir.

\section{Kaynakça}

Adaklı, G. (2014). Medya Sermayesi ve Ultra-Çapraz Bütünleşmeler, Perspectives: Siyasi Analiz ve Yorum içinde (18-23), Heinrich Böll Stiftung.

Bagdikian, B. (2004). The New Media Monopoly, Boston: Beacon Press.

Baker, U. (2015). Kanaatlerden İmajlara: Duygular Sosyolojisine Doğru, $(H$. Abuşoğlu, çev.), İstanbul: Birikim Kitapları.

Bennett, T. (1982). Theories of the Media, Theories of Society, Gurevitch, M. (ed.). Culture, Society and the Media içinde (30-55), London: Methuen.

Bourdieu, P (1998a). Acts of Resistance Against the Tyranny of the Market, New York: The New Press.

Bourdieu, P. (2000). Televizyon Üzerine, (T. Ilgaz, çev.), İstanbul: Yapı Kredi Yayınları.

Bourdieu, P. (2001). Masculine Domination, Stanford: Stanford University Press.

Bourdieu, P., Wacquant, L. J. (2007). Düşünümsel Bir Antropoloji Için Cevaplar, Ökten, N (çev.), İstanbul: Illetişim Yayınları.

Bourdieu, P. (2013). Language \& Symbolic Power, Thompson, J.B. (ed.), Cambridge: Polity Press.

Calhaun, C. (2016). Bourdieu, Sosyolojisinin Ana Hatları, Çeğin G., Göker, E., Arlı, A., Tatlıcan, Ü. (der.), Ocak ve Zanaat: Pierre Bouurdieu Derlemesi içinde (77130), İstanbul: Illetişim Yayınları.

Cankaya, Ö. (1997). Türkiye'de Radyo-Televizyonun Gelişme Süreci, İstanbul: Beta Basım Yayım Dağıtım A.Ş.

Çaplı, B. (2008). Fili Tarif Etmek: Özel Televizyona Beş Kala, Ankara: İmge Kitabevi Yayınları.

Darras, E. (2005). Media Consecration of the Political Order, Benson, R., Neveu, E. (ed.), Bourdieu and the Journalistic Field içinde (156-173), Cambridge: Polity Press. 
Duran, R. (2015). Dümdüz, Sessiz, Hareketsiz. Ulvî Gibi Medya Nasıl Kürtaj Edilir?, Aydın, U. (der.), Neoliberal Muhafazakâr Medya içinde (19-30), İstanbul: Ayrıntı Yayınları.

Ertuna, A.C. (2017). Türkiye'de Ana Akım Haber Kanallarında Tartışma Programları ve Kanaat Teknisyenleri, Yayınlanmamış Doktora Tezi. İstanbul: Galatasaray Üniversitesi Sosyal Bilimler Enstitüsü.

Fiske, J. (1999). Television Culture: Popular Pleasures and Politics, London: Routledge.

Garnham, N., Williams, R. (1986). Pierre Bourdieu and the Sociology of Culture: An Introduction, Collins, R., Curran, J., Garnham, N., Scannell, P., Schlesinger, P., Sparks, C. (ed.), Media, Culture \& Society içinde (116-130), London: Sage Publications.

Hall, S. (1973). The Determinations of News Photographs, S. Cohen and J. Young (ed.), The Manufacture of News: A Reader içinde (176-190). CA: Sage.

Hallin, D., Mancini, P. (2004). Comparing Media Systems: Three Models of Media and Politics, Cambridge: Cambridge University Press.

Herman, E., Chomsky, N. (1988). Manufacturing Consent: The Political Economy of the Mass Media, New York: Pantheon Books.

Kaya, R. (2016). İktidar Yumağı: Medya, Sermaye, Devlet, Ankara: İmge Kitabevi. Louw, E. (2010). The Media and Political Process, London: Sage Publications. Moi, T. (1991). Appropriating Bourdieu: Feminist Theory and Pierre Bourdieu's Sociology of Culture, New Literary History, 22:4, 1017-1049.

Nimmo, D., Combs, M. (1992). The Political Pundits, New York: Praeger.

Schudson, M. (2002). The News Media as Political Institutions, Annual Review of Political Science, 2002:5, 249-269.

Sigal, L.V. (1986). Sources make the news, R.K. Manoff ve Michael Schudson (ed.), Reading the news içinde. New York: Pantheon Books.

Thompson, J.B. (2013). Editor's Introduction, Language and Symbolic Power içinde (1-31), Cambridge: Polity Press.

Thornham, S. (2007). Women, Feminism and Media, Edinburgh: Edinburgh University Press.

Tuchman, G. (1978). Making News: A Study in the Construction of Reality, New York: The Free Press.

Türk, B. (2012). AKP ve Kanaat Teknisyenleri, Birikim, 276, 29-37 